\title{
Late Onset Neonatal Herpes Encephalitis: A Case-Based CNS Complication and Neurological Outcome
}

\author{
Surya N. Gupta ${ }^{*}$, Vikash S. Gupta², Nirali Borad ${ }^{3}$ \\ ${ }^{1}$ Section of Child Neurology Women's and Children's Hospital, Charleston Area Medical Center, Charleston, \\ USA \\ ${ }^{2}$ Texila American University, Georgetown, Guyana \\ ${ }^{3}$ Department of Physiology, P.D.U. Government Medical College, Rajkot, India \\ Email: suryangupta@rediffmail.com, 387221@gmail.com, niraliborad@gmail.com
}

Received 7 February 2015; accepted 23 February 2015; published 27 February 2015

Copyright (C) 2015 by authors and OALib.

This work is licensed under the Creative Commons Attribution International License (CC BY).

http://creativecommons.org/licenses/by/4.0/

\section{(c) (i) Open Access}

\begin{abstract}
Individual neurological complication caused by Herpes simplex viruses in neonates is well-known. We report neonatal Herpes encephalitis that caused multiple neurological complications in the same patient during acute phase of illness. Our patient differs from previously reported cases in the following ways: 1) Late onset neonatal presentation; 2) Development of multiple neurologic complications during acyclovir therapy; 3) Cesarean-section did not prevent perinatal transmission of Herpes simplex virus; and 4) Our patient's acute hydrocephalus was managed conservatively and he had no reoccurrence of seizure, hydrocephalus, and no motor deficits. A high degree of suspicion, timely needed supportive medical and surgical care, and prompt initiation of intravenous acyclovir offer the best chance for neurological outcome in neonates with Herpes encephalitis.
\end{abstract}

\section{Keywords}

Neonatal Herpes Encephalitis, Central Nervous System Complication, Acute Hydrocephalus, Intracranial Hemorrhage, Opsoclonus or Dancing eye, Cerebral Palsy

Subject Areas: Neurology

\section{Introduction}

Clinical signs associated with neonatal herpes simplex viral (HSV) infection are variable and its course tends to

"Corresponding author.

How to cite this paper: Gupta, S.N., Gupta, V.S. and Borad, N. (2015) Late Onset Neonatal Herpes Encephalitis: A CaseBased CNS Complication and Neurological Outcome. Open Access Library Journal, 2: e1280.

http://dx.doi.org/10.4236/oalib.1101280 
be rapidly progressive [1]. Neonates usually present with seizure with or without fever preceded by undetermined lethargy. In such scenario, their cerebrospinal fluid (CSF) is examined by polymerase chain reaction (PCR) for HSV DNA. An urgent magnetic resonance imaging (MRI) is indicated during early course of the illness. The MRI identifies the predilection of the HSV for temporal and extra-temporal gray matter leading to hemorrhagic encephalitis [2].

The individual neurological complications in isolation such as intracerebral or intraventricular hematoma, hydrocephalus, ischemic stroke, opsoclonus with and without myoclonus, Wallenberg's lateral medullary syndrome, acute retinal necrosis, and uncal herniation have been reported in the past [3]-[9].

Authors report late onset neonatal Herpes encephalitis in a single patient who developed multiple neurological complications in acute phase of his illness. Authors provide evidence-based cases review of central nervous system (CNS) complications and outcome in neonates with Herpes encephalitis.

\section{Case Report}

An 8-week-old boy was brought to a tertiary University Children's Medical Center Emergency Department (ED) for continued fever $\left(39^{\circ} \mathrm{C}\right)$, poor feeding, and being "fussy" for the past five days. His birth history was complicated by early rupture of the membrane and cesarean section (C-section). He had multiple seizures without regaining consciousness. Emergency management of status epilepticus was initiated with intravenous (IV) lorazepam $(0.14 \mathrm{mg} / \mathrm{kg}$ in two divided doses) and phenobarbital $(20 \mathrm{mg} / \mathrm{kg})$. The emergency medical interventions terminated the status. IV ampicillin, cefotaxime, and acyclovir (60 mg/kg/day) were started in the ED. Four days prior to admission, past medical history included inpatient medical care with empirical treatment for bacterial meningitis.

Examination in pediatric intensive care unit revealed a lethargic child with stable vitals. Head circumference was 39 centimeter ( $50^{\text {th }}$ percentile) and anterior fontanel was open and soft. There were no mucocutaneous lesions. His pupils were equal and reactive to light. The eye movements were in full.

The routine blood tests, serum biochemistry, and coagulation profile, all were normal. Initial brain computerized tomography (CT) demonstrated a normal ventricular size and preservation of white matter-gray matter junction (Figure 1(a)). CSF studies revealed a white blood cell count of $160 / \mathrm{mm}^{3}$ (predominantly lymphocytes), red blood cells of 2900/ $\mathrm{mm}^{3}$, protein of $186 \mathrm{mg} / \mathrm{dl}$, and glucose of $35 \mathrm{mg} / \mathrm{dl}$. Serum glucose was $83 \mathrm{mg} / \mathrm{dl}$ (normal 65 - 110). CSF culture revealed no bacterial growth. Polymerase chain reaction (PCR) was positive for HSV-2 DNA and it was negative for HSV-1 DNA. Nasal swab culture for Enteroviruses was negative. The electroencephalogram and brain magnetic resonance imaging (MRI) findings were consistent with the right temporal-frontal encephalitis. His ophthalmic examination was normal.

On day six, he developed chaotic eyes movements of varying amplitudes (opsoclonus) without facial movements (myoclonus). A stat follow-up brain CT scan revealed hydrocephalus, intraparenchymal and intraventricular hemorrhages. They were monitored clinically with the use of head ultrasound. His hydrocephalus was treated conservatively. A follow up brain CT, two 2 weeks after acyclovir therapy, is shown in Figure 1(b).

He completed a 21-day course of IV acyclovir therapy. He was discharged on phenobarbital. During the first two years of follow-up, his eye movements returned to normal. There was no reoccurrence of seizure, HSE, or hydrocephalus. He had no motor deficits.

\section{Discussion}

Neonatal Herpes simplex encephalitis (HSE) is most commonly (70\%) caused by HSV-2. By contrast, virtually all adults HSE are caused by HSV-1. The fetus acquires HSV-2 infection through shedding of the virus during vaginal delivery [10]. An elective C-Section is usually performed to prevent transmission of virus in suspected mothers. In our case, the mother was asymptomatic. Because of non-progressive labor for 21 hours, the child was delivered by C-Section. But this did not prevent the transmission of the virus. We believe that the patient acquired an ascending infection in the presence of an early rupture of the membrane prior to C-section.

Like this case, an early diagnosis remains a significant problem. This may relate to the rarity of the condition. Non-specific CSF pleocytosis, the finding suggesting partially treated bacterial meningitis, and a false negative CSF PCR in the early course of the disease may delay the diagnosis [11]. Additionally, lack of abnormality on initial brain CT and delay in obtaining MRI of the brain could further delay the diagnosis. 


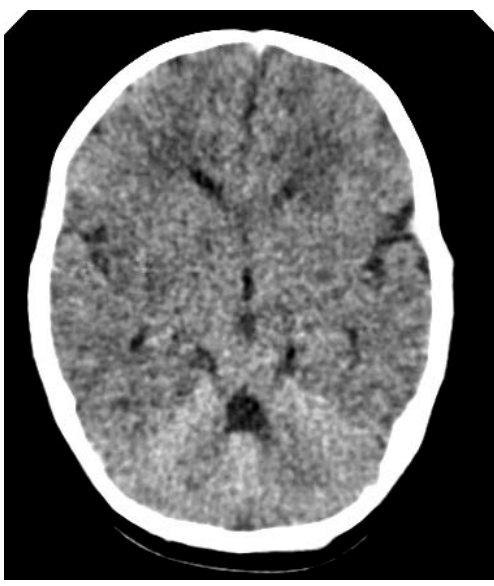

(a)

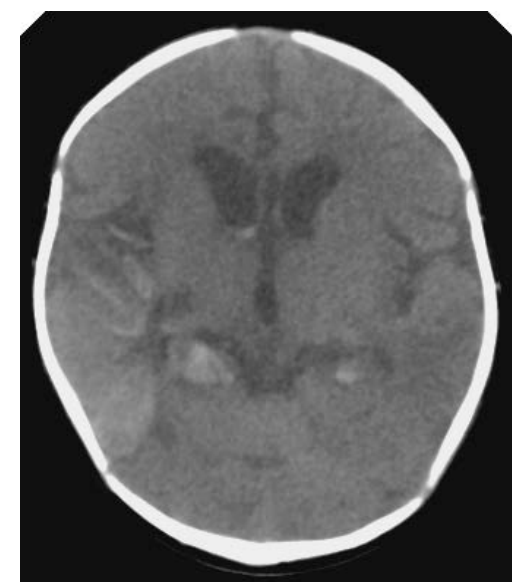

(b)

Figure 1. Computerized tomography of the brainaxial cross-sectional images at third ventricle. (a) Prior to start antiviral therapy shows a normal ventricular size, a normal cerebrospinal spinal fluid signal, and the preservation of frontal white matter-gray matter junctions; (b) Two weeks after acyclovir therapy at one level above (a) shows loss of white matter-gray matter differentiation, hyper dense right frontotemporal, right frontal horn and both occipital horns suggesting intraparenchymal and intraventricular hemorrhage, respectively. Note: A global enlargement of ventricles, including fourth which is not seen at this level.

The pathogenesis of multiple complications, intracerebral and intraventricular hemorrhage and communicating hydrocephalus may have been caused by a combined effect of an initial delay in diagnosis and intracerebral hemorrhage leading to intraventricular hemorrhage. Compromise in cerebro-vascular (arterial and venous circulation) would result in an impedance or inability to absorb CSF efficiently by arachnoid villi at the superior sagittal sinus. Such functional blockage has been reported to occur after intracranial hemorrhage.

Opsoclonus-myoclonus-syndrome is usually associated with diseases of the brainstem and cerebellum. This has been reported, but it is not limited to neuroblastoma, varicella-zoster, West Nile and Enteroviruses in adult and pediatric populations. This is thought to be a result of an autoimmune response directed against cross-reactive proteins of offending agents and neuronal cells. The cause of an isolated opsoclonus without myoclonus in our case remains speculative. Contrary to Krolczyk S et al. (2003), description of opsoclonus as a possible early sign of HSV-2 CNS infection, our patient opsoclonus developed during acyclovir therapy [12].

\section{Literature Search and the Results}

We performed PubMed online search for English literature for infants and neonatal herpes encephalitis. We used terms "Herpes simplex virus 1 and 2", "Herpes Encephalitis”, "hydrocephalus”, “CNS complication”, neurological outcome in isolation or combination with either neonate or infant. Bibliography of the reports was searched for additional information.

The results of our search are shown in Table 1 [12]-[26].

Combined CNS complications occurred in 32/48 (67\%) neonates. In HSV-1 group, 6 neonates (40\%) and HSV-2 group, 26 (79\%) had neurological complications. In HSV-1 group; 9 (64\%) and in HSV-2 group; 7 (21\%) had no neurologic sequelae. No deaths were reported in neonates with HSV-1. Two patients with hypertonicity were excluded in the graph. Neonates with no HSV typing done were excluded from the study.

Why our patient had good neurological outcome despite multiple complications? Probably, this relates to severity of the infection and maturity level of the brain, as our patient presented at age 8 weeks. The literature search revealed age ranges of neonatal Herpes encephalitis between births to a maximum of 26th days.

\section{Conclusions}

In conclusion, awareness of these complications together with previously reported entities will allow acting in timely manner. Acute hydrocephalus is a potentially life-threatening and a treatable surgical complication of 
Table 1. Shows combined summary of the reports clinical demography for central nervous system complications in 48 neonates with Herpes simplex encephalitis type 1 and 2.

\begin{tabular}{|c|c|c|c|c|c|}
\hline & Clinical presentation & $\begin{array}{l}\text { Antiviral } \\
\text { initiation }\end{array}$ & $\begin{array}{l}\text { HSV } \\
\text { type }\end{array}$ & $\begin{array}{l}\text { Acute CNS } \\
\text { complication }\end{array}$ & $\begin{array}{l}\text { Neurologic outcome } \\
\text { [reference] }\end{array}$ \\
\hline At birth/boy & Mucocutaneous lesions & 4 days/yes & 2 & NA & $\begin{array}{l}\text { Developmental delay, } \\
\text { quadriplegia [13] }\end{array}$ \\
\hline At birth/boy & $\begin{array}{l}\text { Lethargy, mucocutaneous } \\
\text { vesicles }\end{array}$ & 15 days/no & 2 & Necrotizing retinitis & $\begin{array}{l}\text { Death-cause was not } \\
\text { specified [14] }\end{array}$ \\
\hline At birth/girl & $\begin{array}{c}\text { Skin lesions and severe } \\
\text { jitteriness }\end{array}$ & NA & 2 & $\begin{array}{l}\text { Seizures, apnea, } \\
\text { abnormal posture }\end{array}$ & $\begin{array}{c}\text { Died-increased seizures, } \\
\text { otherwise cause not } \\
\text { specified [15] }\end{array}$ \\
\hline At birth/boy & $\begin{array}{l}\text { Generalized seizures, } \\
\text { Lethargy, Full anterior } \\
\text { fontanelle }\end{array}$ & NA & 2 & $\begin{array}{l}\text { Large and tiny hemorrhages } \\
\text { in cerebellar hemispheres }\end{array}$ & $\begin{array}{c}\text { Died-supportive care } \\
\text { discontinued due to poor } \\
\text { prognosis [16] }\end{array}$ \\
\hline 2 hours/boy & Focal seizures and Apnea & 18 hours/yes & 2 & Encephalomalacia & $\begin{array}{c}\text { Died; due to fulminant } \\
\text { necrotizing enterocolitis } \\
\text { [17] }\end{array}$ \\
\hline 2 days/boy & $\begin{array}{l}\text { Lethargy, Apnea, } \\
\text { and hypopnea }\end{array}$ & 4.5 hours/yes & 2 & NA & No sequelae [18] \\
\hline 7 days/girl & Clonic jerking of right side & 2 days/yes & 1 & $\begin{array}{l}\text { Recurrent Obstructive } \\
\text { hydrocephalus }\end{array}$ & $\begin{array}{l}\text { Ventriculostomy needed } \\
\text { three times [19] }\end{array}$ \\
\hline 9 days/girl & $\begin{array}{l}\text { Vesicles on occipital } \\
\text { and parietal scalp }\end{array}$ & $<1$ day/yes & 1 & None & No sequelae [20] \\
\hline 9 days/girl & $\begin{array}{l}\text { Apnea, bradycardia, } \\
\text { and encephalitis }\end{array}$ & $<1$ day/yes & 1 & $\begin{array}{c}\text { Left parietal } \\
\text { Encephalomalacia with } \\
\text { hemorrhagic component }\end{array}$ & $\begin{array}{l}\text { Seizures and significant } \\
\text { developmental delay [20] }\end{array}$ \\
\hline 9 days/girl & Seizures & 4 days/yes & 2 & NA & $\begin{array}{l}\text { Developmental delay } \\
\text { and quadriplegia }\end{array}$ \\
\hline 10 days/girl & $\begin{array}{l}\text { Pustular rashes over the } \\
\text { eyelid and encephalitis }\end{array}$ & $<6$ hours/yes & 2 & NA & No sequelae [13] \\
\hline 10 days/girl & $\begin{array}{l}\text { Apnea, lethargy, } \\
\text { encephalitis }\end{array}$ & 5 days/yes & 2 & $\begin{array}{l}\text { Recurrent Herpes simplex } \\
\text { virus encephalitis }\end{array}$ & $\begin{array}{l}\text { Oromotor dysfunction, } \\
\text { extensor posturing, and } \\
\text { axial hypotonia [18] }\end{array}$ \\
\hline 13 days/girl & $\begin{array}{l}\text { Generalized myoclonic } \\
\text { seizures, lethargy }\end{array}$ & 7 days/yes & 2 & Cerebral malakoplakia & $\begin{array}{c}\text { Death-secondary to chronic } \\
\text { meningoencephalitis [21] }\end{array}$ \\
\hline 14 days/girl & $\begin{array}{l}\text { Seizures, flaccid paralysis, } \\
\text { left ptosis. }\end{array}$ & 2 days/yes & 2 & $\begin{array}{c}\text { Spastic right hemiplegia, } \\
\text { chorioretinitis, homonymous } \\
\text { hemianopia }\end{array}$ & $\begin{array}{l}\text { Microcephaly, multi-cystic } \\
\text { encephalomalacia [22] }\end{array}$ \\
\hline 15 days/girl & $\begin{array}{l}\text { Focal seizures, } \\
\text { apneic episodes }\end{array}$ & 3 days/yes & 2 & $\begin{array}{c}\text { Megacystic encephalomalacia, } \\
\text { Cortical atrophy and } \\
\text { Subdural effusions }\end{array}$ & $\begin{array}{l}\text { Developmental delay, } \\
\text { hypertonicity, and } \\
\text { microcephaly [17] }\end{array}$ \\
\hline 15 days/girl & Seizures & $<1$ day/yes & 1 & NA & $\begin{array}{l}\text { Developmental delay, } \\
\text { quadriplegia [13] }\end{array}$ \\
\hline 16 days/girl & $\begin{array}{c}\text { Lethargy, Facial diplegia, } \\
\text { and Hypotonia }\end{array}$ & 1 day/yes & 2 & $\begin{array}{c}\text { Hypotonia, } \\
\text { and Hyperreflexia }\end{array}$ & $\begin{array}{l}\text { Developmental delay, } \\
\text { hypertonia, and } \\
\text { hyperreflexia [23] }\end{array}$ \\
\hline 17 days/girl & $\begin{array}{l}\text { Focal clonic upper } \\
\text { limb seizures }\end{array}$ & 2 days/yes & 1 & Acute retinal necrosis & $\begin{array}{l}\text { Poor vision in the } \\
\text { left eye [24] }\end{array}$ \\
\hline 17 days/girl & $\begin{array}{c}\text { Seizures and } \\
\text { mucocutaneous lesions }\end{array}$ & 2 days/yes & 2 & NA & $\begin{array}{l}\text { Developmental delay, } \\
\text { and quadriplegia [13] }\end{array}$ \\
\hline
\end{tabular}




\section{Continued}

\begin{tabular}{|c|c|c|c|c|c|}
\hline 18 days/girl & Seizures & 2 days/yes & 2 & NA & $\begin{array}{l}\text { Developmental delay, } \\
\text { and quadriplegia [13] }\end{array}$ \\
\hline 20 days/girl & Generalized seizures & 7 days/yes & 1 & $\begin{array}{l}\text { Oro-glosso-pharyngeal } \\
\text { paralysis }\end{array}$ & $\begin{array}{l}\text { Epilepsy, opercular syndrome, } \\
\text { and cerebral palsy [25] }\end{array}$ \\
\hline 20 days/girl & Seizures & 2 days/yes & 2 & NA & $\begin{array}{l}\text { Developmental delay, } \\
\text { Hemiparetic cerebral } \\
\text { palsy [13] }\end{array}$ \\
\hline 23 days/girl & Generalized seizures & 5 days/yes & 2 & $\begin{array}{c}\text { Severe bilateral } \\
\text { Encephalomalacia, and } \\
\text { chorioretinitis }\end{array}$ & $\begin{array}{l}\text { Severe developmental delay } \\
\text { and epilepsy [17] }\end{array}$ \\
\hline 26 days/girl & Lethargy and opsoclonus & 4 days/yes & 2 & Seizures & No sequelae [12] \\
\hline 1 - 15 days/NA & $\begin{array}{l}\text { Lethargy, poor feeding, } \\
\text { cutaneous lesions }\end{array}$ & 3 - 8 days/yes & 1 & Unknown & $\begin{array}{c}\text { Eight neonates had no } \\
\text { sequelae [26] } \\
1 \text { had canalicular and } \\
\text { cornealscarring }\end{array}$ \\
\hline \multirow{3}{*}{1 - 15 days/NA } & \multirow{3}{*}{$\begin{array}{l}\text { Lethargy, poor feeding, } \\
\text { and cutaneous lesions }\end{array}$} & NA & & \multirow{3}{*}{ Unknown } & $\begin{array}{l}\text { One neonate died due to } \\
\text { encephalitis }[26]\end{array}$ \\
\hline & & 2 - 6 days/yes & 2 & & $\begin{array}{l}\text { Four neonates had } \\
\text { no sequelae }\end{array}$ \\
\hline & & 0 - 10 days/yes & & & $\begin{array}{c}\text { Ten neonates with neurologic } \\
\text { sequelae are included } \\
\text { in the bar graph }\end{array}$ \\
\hline
\end{tabular}

NA, data not available. Foot note: our patient differs from previously reported cases in the following ways: 1) a late neonatal presentation; 2) a C-section did not prevent perinatal transmission; 3) Multiple CNS complications, opsoclonus, intraparenchymal and intraventricular hemorrhage, and acute hydrocephalus in the same patient. Additionally, our case required an emergent neurosurgical intervention. Two neonates, one neonate was diagnosed by positive serology testing [27] and another by PCR but no HSV typing [28], both were excluded from the Table 1 and Graph 1.

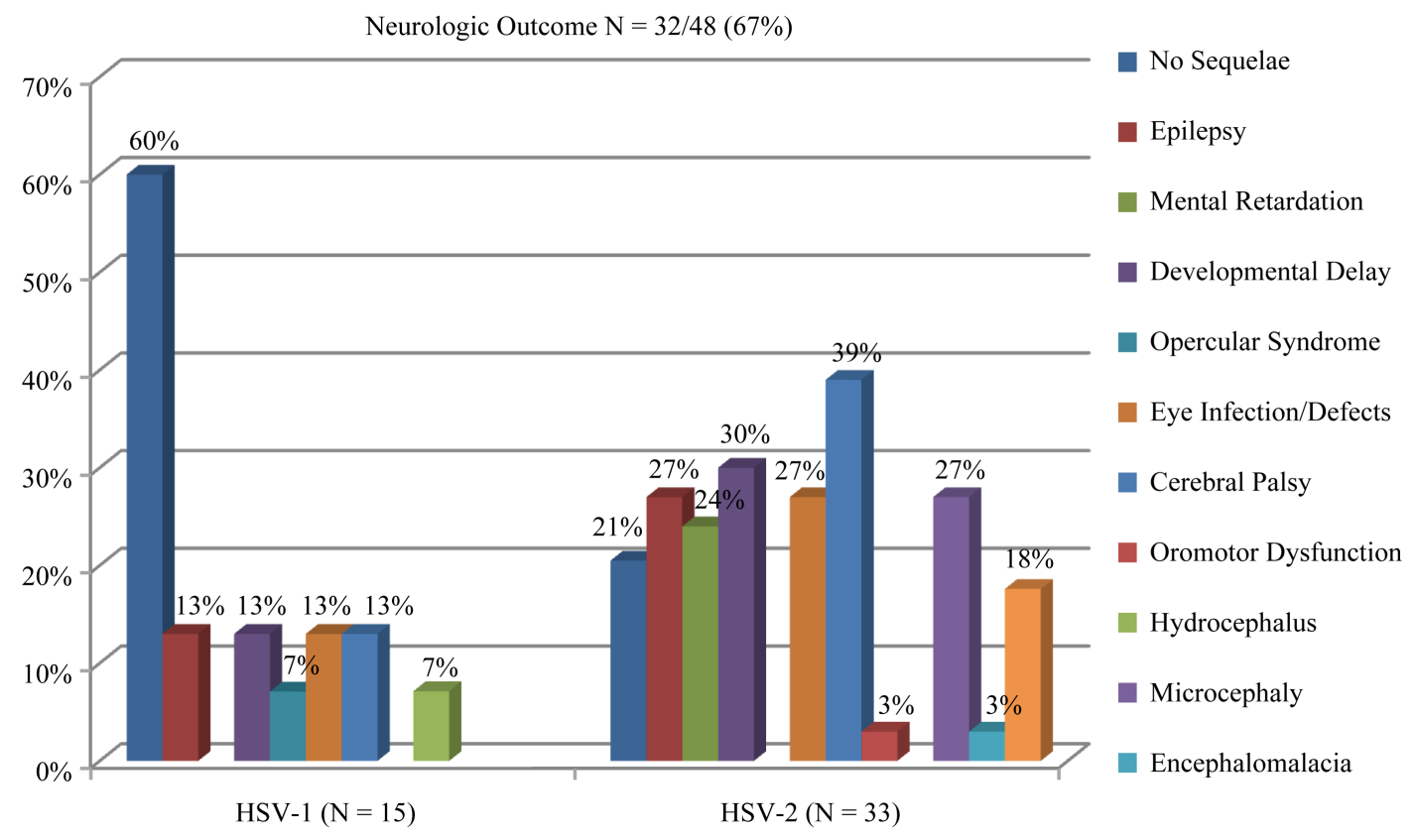

Graph 1. Is showing neurologic outcome of neonates with combined herpes simplex encephalitis type 1 and 2. Combined CNS complications occurred in 32/48 (67\%) neonates. In HSV-1 group, 6 neonates (40\%) and HSV-2 group, 26 (79\%) had neurologic complications. In HSV-1 group, 9 (64\%) and in HSV-2 group; 7 (21\%) had no neurologic sequelae. No deaths were reported in neonates with HSV-1. Two patients with hypertonicity were excluded in the graph. Neonates with no HSV typing done were excluded from the study. 
Herpes encephalitis. These actions alone may not prevent the CNS complication. For this reason, primary prevention of perinatal transmission of herpes by considering an elective C-section remains important.

A high degree of suspicion, timely needed supportive medical and surgical care, and prompt initiation of intravenous acyclovir offer the best chance to improve morbidity and mortality of neonatal herpes encephalitis.

\section{Conflict of Interest}

None.

\section{References}

[1] Whitley, R.J. and Lakeman, F. (1995) Herpes Simplex Infections of the Central Nervous System: Therapeutic and Diagnostic Considerations. Clinical Infectious Diseases, 20, 414-420. http://dx.doi.org/10.1093/clinids/20.2.414

[2] Mekan, S.F., Wasay, M., Khelaeni, B., Saeed, Z., Hassan, A. and Sheerani, M. (2005) Herpes Simplex Encephalitis: Analysis of 68 Cases from a Tertiary Care Hospital in Karachi, Pakistan. Journal of Pakistan Medical Association, 55, 146-148.

[3] Biswas, A., Das, S.K., Roy, T., et al. (2004) Acute Intracerebral Haematoma-An Unusual Presentation of Herpes Simplex Encephalitis. Journal of the Association of Physicians of India, 52, 69-71.

[4] Ronald, E.H. and Hill, A. (1997) Intraventricular Hemorrhage: Germinal Matrix-Intraventricular Hemorrhage and Post Hemorrhagic Hydrocephalus: Current and Future Intervention. Clinics in Perinatology, 24, 589-605.

[5] Imtiaz, K.E. and Vora, J.P. (1999) Dancing Eyes-Dancing Feet. Lancet, 354, 390. http://dx.doi.org/10.1016/S0140-6736(99)05250-2

[6] Alexandri, N.M., Tavernarakis, A., et al. (2004) Ischemic Stroke and Herpes Simplex Virus Type-1 Associated Meningoencephalitis. Revista de Neurologia (Paris), 160, 579-581. http://dx.doi.org/10.1016/S0035-3787(04)70991-1

[7] Uunca, A. and Bavbek, N. (2004) An Atypical Herpes Encephalitis with Wallenberg's Lateral Medullary Syndrome and CD Receptors Deficiency. Acta Medica (Hradec Kralove), 47, 55-58.

[8] Cardine, S., Chaze, P.A., Bourcier, F., et al. (2004) Bilateral Acute Retinal Necrosis Syndrome Associated with Meningoencephalitis Caused by Herpes Simplex Virus 2. A Case Report. Journal Francais D Ophtalmologie, 27, 795800. http://dx.doi.org/10.1016/S0181-5512(04)96216-X

[9] Kannu, P. and Pinnock, R. (2004) Uncommon Complication of Herpes Simplex Encephalitis. Journal of Paediatrics and Child Health, 40, 711-713. http://dx.doi.org/10.1111/j.1440-1754.2004.00517.x

[10] Whitley, R.J. (2004) Herpes Simplex Virus Infections. In: Goldman, L. and Ausiello, D., Eds., Cecil Textbook of Medicine, 22nd Edition, W.B. Saunders Company, Philadelphia, 1991-1992.

[11] De Tiege, X., Heron, B., Lebon, P., Ponsot, G. and Rozenberg, F. (2003) Limits of Early Diagnosis of Herpes Simplex Encephalitis in Children: A Retrospective Study of 38 Cases. Clinical Infectious Diseases, 36, 1335-1339. http://dx.doi.org/10.1086/374839

[12] Krolczyk, S., Pacheco, E., Valencia, P., Papazian, O., Yelin, K. and Alfonso, I. (2003) Opsoclonus: An Early Sign of Neonatal Herpes Encephalitis. Journal of Child Neurology, 18, 356-358. http://dx.doi.org/10.1177/08830738030180050201

[13] Engman, M.L., Adolfsson, I., Lewensohn-Fuchs, I., Forsgren, M., Mosskin, M. and Malm, G. (2008) Neuropsychologic Outcomes in Children with Neonatal Herpes Encephalitis. Pediatric Neurology, 38, 398-405. http://dx.doi.org/10.1016/j.pediatrneurol.2008.02.005

[14] Greer, C.H. (1980) Bilateral Necrotizing Retinitis Complicating Fatal Encephalitis Probably Due to Herpes Simplex Virus Type 2. Ophthalmologica, 180, 146-150. http://dx.doi.org/10.1159/000308969

[15] Suh, Y.L., Kim, H., Chi, J.G., Byun, H.R. and Lee, K. (1987) Disseminated Neonatal Herpes Simplex Virus Infection with Necrotizing Encephalitis: An Autopsy Case. Journal of Korean Medical Science, 2, 123-127. http://dx.doi.org/10.3346/jkms.1987.2.2.123

[16] Abzug, M.J. and Johnson, S.M. (2000) Catastrophic Intracranial Hemorrhage Complicating Perinatal Viral Infections. Pediatric Infectious Disease Journal, 19, 556-560. http://dx.doi.org/10.1097/00006454-200006000-00013

[17] Mejías, A., Bustos, R., Ardura, M.I., Ramírez, C. and Sánchez, P.J. (2009) Persistence of Herpes Simplex Virus DNA in Cerebrospinal Fluid of Neonates with Herpes Simplex Virus Encephalitis. Journal of Perinatology, 29, 290-296. http://dx.doi.org/10.1038/jp.2008.235

[18] O’Riordan, D.P., Golden, W.C. and Aucott, S.W. (2006) Herpes Simplex Virus Infections in Preterm Infants. Pediatrics, 118, e1612-e1620.

[19] Tyagi, A., Chumas, P. and Ferrie, C. (2001) Obstructive Hydrocephalus Following Herpes Simplex Virus Type 1 En- 
cephalitis Treated by Repeated Third Ventriculostomy. Pediatric Neurosurgery, 34, 244-246. http://dx.doi.org/10.1159/000056031

[20] Peng, J., Krause, P.J. and Kresch, M. (1996) Neonatal Herpes Simplex Virus Infection after Cesarean Section with Intact Amniotic Membranes. Journal of Perinatology, 16, 397-399.

[21] Volk, E., Parker Jr., J.C. and Tepper, S. (1992) Cerebral Malakoplakia Associated with Neonatal Herpes Virus Infection. Annals of Clinical \& Laboratory Science, 22, 300-306.

[22] Smith, J.B., Groover, R.V., Klass, D.W. and Houser, O.W. (1977) Multicystic Cerebral Degeneration in Neonatal Herpes Simplex Virus Encephalitis. American Journal of Diseases of Children, 131, 568-572.

[23] Pelligra, G., Lynch, N., Miller, S.P., Sargent, M.A. and Osiovich, H. (2007) Brainstem Involvement in Neonatal Herpes Simplex Virus Type 2 Encephalitis. Pediatrics, 120, e442-e446. http://dx.doi.org/10.1542/peds.2006-3757

[24] Fong, C.Y., Aye, A.M., Peyman, M., Nor, N.K., Visvaraja, S., Tajunisah, I. and Ong, L.C. (2014) Neonatal Herpes Simplex Virus Type-1 Central Nervous System Disease with Acute Retinal Necrosis. Pediatric Infectious Disease Journal, 33, 424-426. http://dx.doi.org/10.1097/INF.0000000000000137

[25] García-Ribes, A., Martínez-González, M.J. and Prats-Viñas, J.M. (2007) Suspected Herpes Encephalitis and Opercular Syndrome in Childhood. Pediatric Neurology, 36, 202-206. http://dx.doi.org/10.1016/j.pediatrneurol.2006.10.006

[26] Corey, L., Whitley, R.J., Stone, E.F. and Mohan, K. (1988) Difference between Herpes Simplex Virus Type 1 and Type 2 Neonatal Encephalitis in Neurological Outcome. Lancet, 1, 1-4.

[27] Shian, W.J. and Chi, C.S. (1994) Herpes Simplex Encephalitis in Infants and Children. Zhonghua Yi Xue Za Zhi (Taipei), 53, 19-26.

[28] Toth, C., Harder, S. and Yager, J. (2003) Neonatal Herpes Encephalitis: A Case Series and Review of Clinical Presentation. Canadian Journal of Neurological Sciences, 30, 36-40. http://dx.doi.org/10.1017/S0317167100002419

\section{Abbreviations \\ CNS: central nervous system; \\ CSF: cerebrospinal fluid; \\ CT: computerized tomography.}


Scientific Research Publishing (SCIRP) is one of the largest Open Access journal publishers. It is currently publishing more than 200 open access, online, peer-reviewed journals covering a wide range of academic disciplines. SCIRP serves the worldwide academic communities and contributes to the progress and application of science with its publication.

Other selected journals from SCIRP are listed as below. Submit your manuscript to us via either submit@scirp.org or Online Submission Portal.
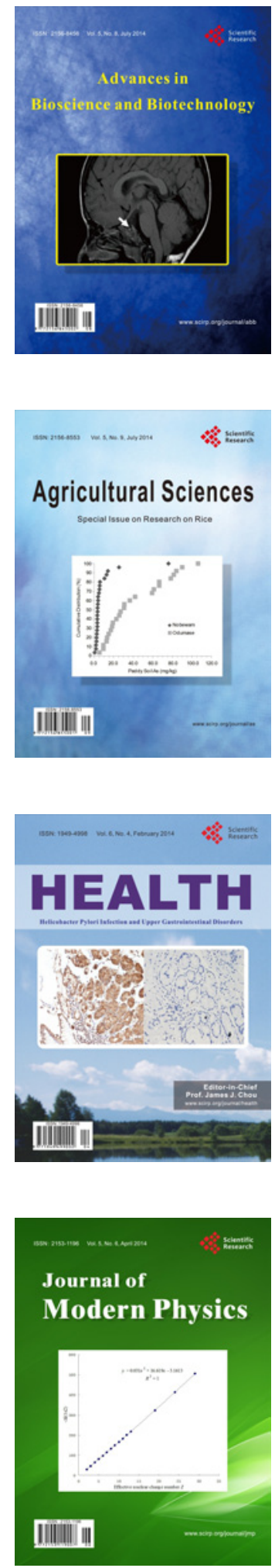
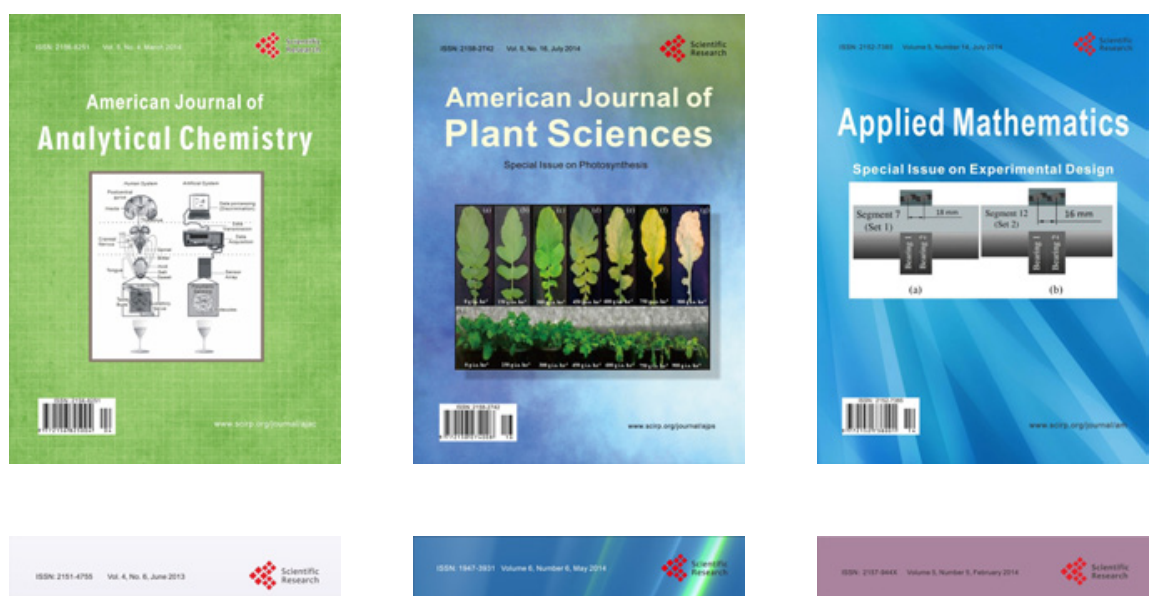

Creative Education
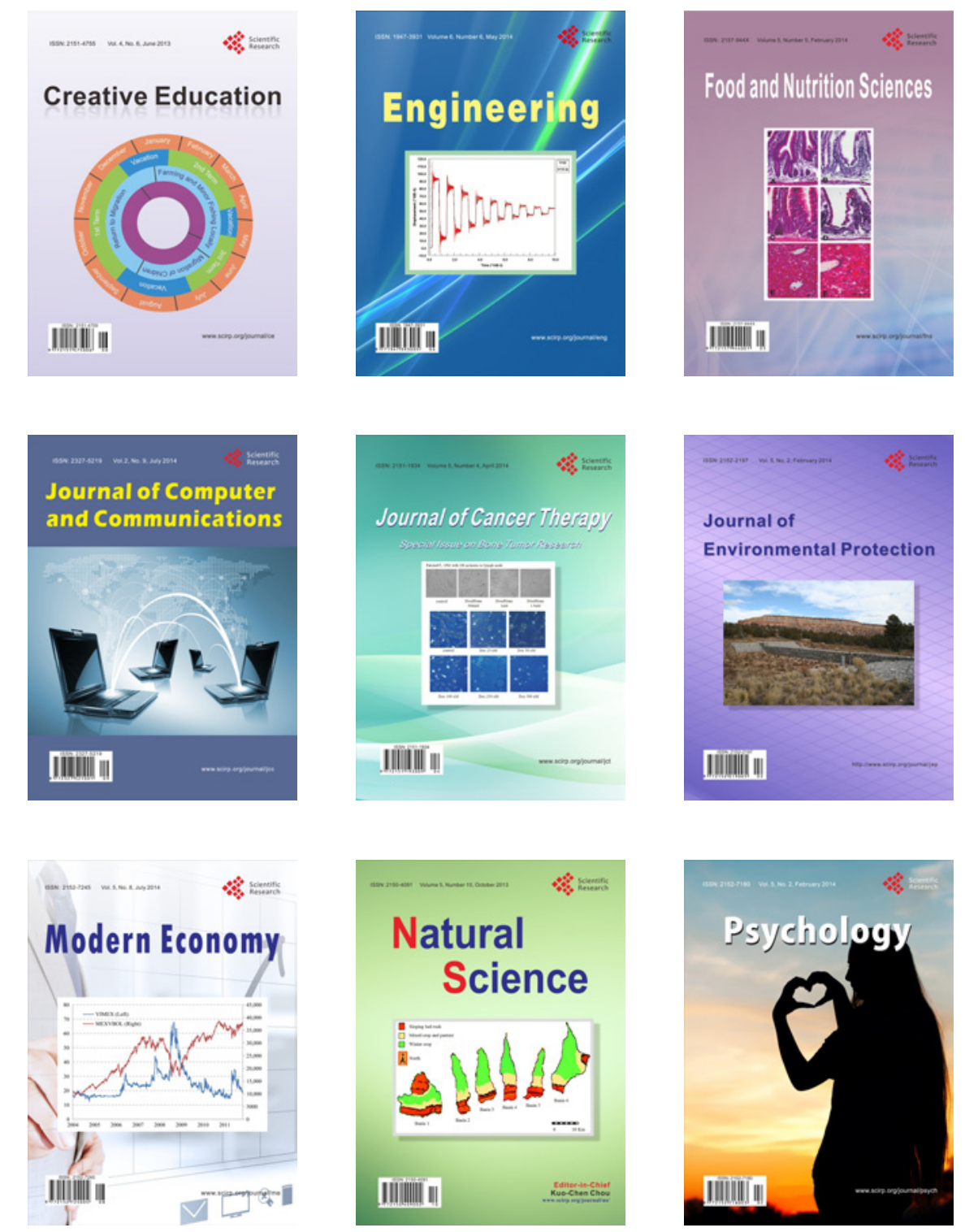